SocioEconomic Challenges, Volume 4, Issue 4, 2020

ISSN (print) - 2520-6621, ISSN (online) - 2520-6214

\title{
Energy Efficiency Of National Economy: Social, Economic And Ecological Indicators
}

\author{
https://doi.org/10.21272/sec.4(4).160-174.2020
}

Yevheniia Ziabina, ORCID: https://orcid.org/0000-0003-0832-7932

Department of Marketing, Sumy State University, Ukraine

Tetyana Pimonenko, ORCID: https://orcid.org/0000-0001-6442-3684

Doctor of Economics, Associate Professor, Department of Marketing, Sumy State University, Ukraine

Luidmyla Starchenko, ORCID: https://orcid.org/0000-0001-8606-7246

$\mathrm{PhD}$, Associate Professor, Department of Marketing, Sumy State University, Ukraine

\begin{abstract}
The paper aimed to formalise the relationship between the level of Ukrainian energy efficiency from 30 indicators of social, ecological and economic development of the country. The main purpose of the study is to identify the impact and dependence of socio-ecological and economic indicators on the level of energy efficiency using multiple correlation-regression analysis. The systematisation of the analysed results allowed identifying the core directions to overcome the issues of the slow pace of energy efficiency improvement and the development of carbon neutrality of the country. The relevance of this scientific solution to the problem is that the level of energy efficiency is influenced by a large number of socio-ecological and economic factors sometimes independent of each other. The authors analysed the relationship between the level of energy efficiency and socio-ecological and economic indicators of country development. The investigation consisted from the following stages: conducting polynomial-regression analysis of energy efficiency development in Ukraine; development of correlation-regression multiple models of relationships between energy efficiency indicator and socio-ecological-economic indicators; explaining the conclusions and providing recommendations considering the findings. The object of the study was the processes of energy efficiency relationships with 30 indicators of socio-ecological and economic development, namely how much they affect the energy development of the country. The conclusions were theoretical and practical in terms of the impact on the level of energy efficiency of interdisciplinary indicators. The conclusions which proved by the empirical findings allowed identifying weaknesses in the development of the national economy, as well as to improve and increase the energy potential of the country through energy efficiency development strategies due to the studied determinants that have a strong impact on the level of energy efficiency.
\end{abstract}

Keywords: energy efficiency, carbon-free economy, sustainable development, energy sector, green energy, energy security.

JEL Classification: Q01, Q43, Q56, Q57.

This work is licensed under a Creative Commons Attribution 4.0 International License.

Cite as: Ziabina, Ye., Pimonenko, T., Starchenko, L. (2020). Energy Efficiency Of National Economy: Social, Economic And Ecological Indicators. SocioEconomic Challenges, 4(4), 160-174.

https://doi.org/10.21272/sec.4(4).160-174.2020.

(C) The Authors, 2020. This article is published with open access at Sumy State University.

\section{Introduction}

The results of the analysis of the concept's carbon-free economy evolution showed that in the first stages, this concept was studied only from a theoretical point of view. Moreover, in 2019 the energy policy had become a priority area of country's development around the world. Carbon neutrality implies not only mass transformation 
from traditional to renewable energy (alternative) but also complete thermal modernisation, modification of the production sector in the direction of energy-saving and energy efficiency, innovative changes in treatment systems and recycling, etc. That is, an important engine for the development of a carbon-free economy in the national economy is a set of mechanisms and tools to increase energy efficiency through sustainable innovation. It should be noted that scientists traditionally identify the main indicators and factors that affect on the level of energy efficiency - GDP structure, the energy intensity of GDP, primary and final energy consumption, the energy efficiency of buildings, the share of renewable energy sources in the energy balance, etc. It should be noted that the transition to a carbon-free economy primarily depends on the efficiency of the energy sector, which is of strategic importance to the country. The problem of increasing the level of energy efficiency in Ukraine is one of the important issues to ensure sustainable innovation development and energy independence of the country.

\section{Literature Review}

Many worldwide scientific alliances consider the development of carbon neutrality. It should be noted that the main directions of scientific paper aimed at studying the transition to a carbon-free economy in the context of sustainable development and implementation of energy-efficient solutions in the energy sector have been studied by scientists in such paper of the scientists (Chigrin et al., 2011; Ibragimov et al., 2019; Kostel et al., 2017; Liulov et al., 2019; Makarenko et al., 2017; Ziabina, 2016; Ziabina et al., 2019).

The results of the generalisation of scientific research showed that researchers analysed a different set of factors influencing the transformation processes of the transition to a climate-free economy. Thus, scientists have identified social (Palienko et al., 2017; Pimonenko et al., 2018), ecological (Chygryn et al., 2018; Mačaitytė et al., 2018); Matsenko et al., 2017), economic (Bhowmik, 2019; Bilan et al., 2019) determinants of the impact on macroeconomic stability in reforming the energy sector in the direction of carbon neutrality.

Scientists in the papers (Letunovskaya, 2013; 2014; Olefirenko et al., 2019; Pimonenko et al., 2018) analysed the development of entrepreneurial activity in the transition to a carbon-free economy and green energy, taking into account the socio-ecological and economic characteristics of each state, as well as possible strategies to modify the production of goods and services that could fill larger niches and strengthen competitive positions. At the same time, scientists in (Bozhkova et al., 2018) proved that the increase of innovation potential through the use of marketing, ecological, social, economic tools at the micro and macro levels (Letunovska, 2019; Lyulyov et al., 2017; Samoilikova, 2020; Spremberg et al., 2017; Vashchenko et al., 2018; Singh, 2020) could accelerate the transformation process in the transition to a carbon-neutral economy. The scientists (Chygryn et al., 2018; Ibragimov et al., 2019; Lyeonov et al., 2019; Panchenko et al., 2020; Pavlyk, 2020; Pimonenko, 2018) confirmed that green investment was a catalyst for improving energy efficiency and energy conservation, which was the starting point in the transition to a carbon-free economy. It was expedient to note scientific papers in the direction of studying the impact of climate change on economic activity considering the resource and economic potential and features of each country in the process of the carbon-free vector of development (Kouassi, 2018; Pilia, 2017; Pimonenk et al., 2017; Singh, 2019; Yelnikova et al., 2020; Yevdokimov et al., 2018). Despite powerful scientific background on the investigation of green and climate-neutral economy, the issues on the justification of linking among social, ecological, and economic determinants and efficiency of the energy policy of the country required the further investigation. Considering the findings, the hypothesis of the paper:

$\mathrm{H} 1$ : the indicators of economic, social, and ecological country's development influenced the energy efficiency of the national economy.

\section{Methodology and research methods}

For the analysis the following research method were used: polynomial- and multiple-regresions analysis. Polynomial-regression used for estimation the energy efficiency development of the national economy.

$y_{i}=\alpha_{0}+\alpha_{1} x_{i}+\alpha_{2} x_{i}^{2}+\alpha_{3} x_{i}^{3}+\cdots+\alpha_{n} x^{n}+\varepsilon(i=1,2,3 \ldots, n)$, 


$$
\left[\begin{array}{c}
y_{1} \\
y_{2} \\
y_{3} \\
\ldots \\
y_{n}
\end{array}\right]=\left[\begin{array}{ccccc}
1 & x_{1} & x_{1}^{2} & \ldots & x_{1}^{m} \\
1 & x_{2} & x_{1}^{2} & \ldots & x_{2}^{m} \\
1 & x_{3} & x_{3}^{2} & \ldots & x_{3}^{m} \\
& \ldots & & \\
1 & x_{n} & x_{n}^{2} & \ldots & x_{n}^{m}
\end{array}\right]\left[\begin{array}{c}
\alpha_{0} \\
\alpha_{1} \\
\alpha_{2} \\
\ldots \\
\alpha_{m}
\end{array}\right]+\left[\begin{array}{c}
\varepsilon_{1} \\
\varepsilon_{2} \\
\varepsilon_{3} \\
\ldots \\
\varepsilon_{n}
\end{array}\right]
$$

Multiple correlation-regression analysis used for the checking the relationship between social, ecological, and economic indicators and energy efficiency. Correlation coefficient:

$r=\frac{\sum_{i=1}^{n}\left(X_{i}-\bar{X}\right) \cdot\left(Y_{i}-\bar{Y}\right)}{\sqrt{\sum_{i=1}^{n}\left(X_{i}-\bar{X}\right)^{2} \cdot \sum_{i=1}^{n}\left(Y_{i}-\bar{Y}\right)^{2}}}$

According to Pearson's correlation criteria, the following conditions should be noted:

- Strong direct connection: from 1 to 0.7 ;

- Strong inverse relationship: from -1 to -0.7 ;

- Average direct connection: from 0.699 to 0.3 ;

- Average inverse relationship: from -0.699 to -0.3 ;

- Weak direct connection: from 0.299 to 0 ;

- Weak inverse connection: from -0.299 to 0 .

$R^{2}=1-\frac{\sum_{i=1}^{n}\left(\widehat{y}_{l}-y_{i}\right)^{2}}{\sum_{i=1}^{n}\left(y_{i}-\bar{y}\right)^{2}}$,

$F_{k-1, n-k}=\frac{\frac{1}{k-1} \cdot \sum_{i=1}^{n}\left(\widehat{y}_{l}-\bar{y}\right)^{2}}{\frac{1}{n-k} \cdot \sum_{i=1}^{n}\left(\widehat{y}_{l}-\bar{y}\right)^{2}}$,

$t=\frac{b_{i}-\beta_{i}}{\widehat{\sigma}_{b_{l}}}$.

The object of investigation was Ukraine for 1990-2019 years. Based on the findings in the papers (Pimonenko et al., 2018; Liulov et al., 2019) 10 economic, 10 social and 10 ecological indicators were chosen. The description of the variables and sources were shown in Table 1.

Table 1. Description of the raw variables

\begin{tabular}{|c|c|c|c|c|c|}
\hline Variables & Symbols & Source & Variables & Symbols & Source \\
\hline \multicolumn{4}{|c|}{ Energy efficiency } & Intercept & Eurostat \\
\hline \multicolumn{3}{|c|}{ Social indicators } & \multicolumn{3}{|c|}{ Ecological indicators } \\
\hline Average life expectancy & $\mathrm{X}$ Var1 & World Bank & Final energy consumption & $\mathrm{X}$ Var11 & World Bank \\
\hline Number of retirees & $\mathrm{X}$ Var2 & Ukrstat & $\begin{array}{l}\text { Water is taken from natural water } \\
\text { bodies }\end{array}$ & $\mathrm{X} \operatorname{Var} 12$ & Ukrstat \\
\hline Natural increase, reduction & $\mathrm{X}$ Var3 & Ukrstat & Energy productivity & $\mathrm{X} \operatorname{Var} 13$ & NationMaster \\
\hline Migration growth, reduction & X Var4 & Ukrstat & $\begin{array}{l}\text { The share of primary energy from } \\
\text { renewable sources }\end{array}$ & $\mathrm{X}$ Var14 & World Bank \\
\hline Population & $\mathrm{X}$ Var5 & World Bank & $\begin{array}{l}\text { The average temperature } \\
\text { deviation near the surface }\end{array}$ & $\mathrm{X} \operatorname{Var} 15$ & Eurostat \\
\hline $\begin{array}{l}\text { Number of the economically active } \\
\text { population }\end{array}$ & X Var6 & Ukrstat & $\begin{array}{l}\text { The intensity of greenhouse gas } \\
\text { emissions from energy } \\
\text { consumption }\end{array}$ & $\mathrm{X} \operatorname{Var} 16$ & World Bank \\
\hline Unemployment rate & $\mathrm{X} \operatorname{Var} 7$ & Ukrstat & Volumes of pollutant emissions & $\mathrm{X}$ Var17 & NationMaster \\
\hline $\begin{array}{l}\text { Number of people with higher } \\
\text { education }\end{array}$ & X Var8 & Ukrstat & $\begin{array}{l}\text { The volume of generated waste of } \\
\text { I-III classes of danger from the } \\
\text { economic activity of enterprises } \\
\text { and organisations }\end{array}$ & $\mathrm{X}$ Var18 & Ukrstat \\
\hline $\begin{array}{l}\text { The population on the brink of } \\
\text { poverty }\end{array}$ & X Var9 & Ukrstat & $\mathrm{CO} 2$ emissions from transport & $\mathrm{X} \operatorname{Var} 19$ & NationMaster \\
\hline $\begin{array}{l}\text { Share of household expenditures on } \\
\text { housing and utilities }\end{array}$ & $\mathrm{X}$ Var10 & Ukrstat & $\begin{array}{l}\text { Annual change in interest in } \\
\text { renewable energy production }\end{array}$ & $\mathrm{X}$ Var20 & World Bank \\
\hline
\end{tabular}


Table 1 (cont.). Description of the raw variables

\begin{tabular}{|c|c|c|c|c|c|}
\hline Variables & Symbols & Source & Variables & Symbols & Source \\
\hline \multicolumn{4}{|c|}{ Energy efficiency } & Intercept & Eurostat \\
\hline \multicolumn{3}{|c|}{ Social indicators } & \multicolumn{3}{|c|}{ Ecological indicators } \\
\hline \multicolumn{6}{|c|}{ Economic indicators } \\
\hline $\begin{array}{l}\text { Current costs of environmental } \\
\text { protection }\end{array}$ & $\mathrm{X}$ Var21 & Ukrstat & $\begin{array}{c}\text { The volume of transported } \\
\text { passengers }\end{array}$ & X Var26 & Ukrstat \\
\hline GDP per capita & $\mathrm{X}$ Var22 & NationMaster & Consumer price index & $\mathrm{X}$ Var27 & Ukrstat \\
\hline Industrial production indices & $\mathrm{X}$ Var23 & Ukrstat & $\begin{array}{l}\text { The share of the number of } \\
\text { innovatively active enterprises in } \\
\text { the total number of industrial } \\
\text { enterprises }\end{array}$ & $\mathrm{X}$ Var28 & NationMaster \\
\hline Agricultural production indices & $\mathrm{X}$ Var24 & Ukrstat & $\begin{array}{l}\text { Foreign direct investment, net } \\
\text { inflow }\end{array}$ & X Var29 & World Bank \\
\hline The volume of transported goods & $\mathrm{X}$ Var25 & Ukrstat & $\begin{array}{c}\text { Energy intensity vs GDP per } \\
\text { capita }\end{array}$ & $\mathrm{X} \operatorname{Var} 30$ & World Bank \\
\hline
\end{tabular}

Sources: developed by the authors.

\section{Results}

The findings confirmed that Ukraine was an energy-dependent country, as Ukraine imported more than $50 \%$ of energy consumption. It was caused not only by the inability to meet the needs of their internal energy resources but also by the low level of energy efficiency and energy saving when using the energy potential. Increasing the level of energy efficiency at the micro and macro levels could improve the competitive position on the world stage and increase the level of energy security of the national economy.

The results of the study showed that in the scientific community, there is no single accepted term for energy efficiency:

- energy efficiency - an indicator that reflects the ratio of the beneficial effect of the use of energy resources to their cost;

- energy efficiency - an indicator that characterises the efficient, rational use of energy resources, which under conditions of economic development does not tend to increase.

The Ukrainian energy efficiency potential was estimated based on the sample of the energy efficiency level from 2000 to 2019, using the polynomial regression analysis. Graphic interpretation of the results of the energy efficiency assessment of the national economy was presented in Fig.1.

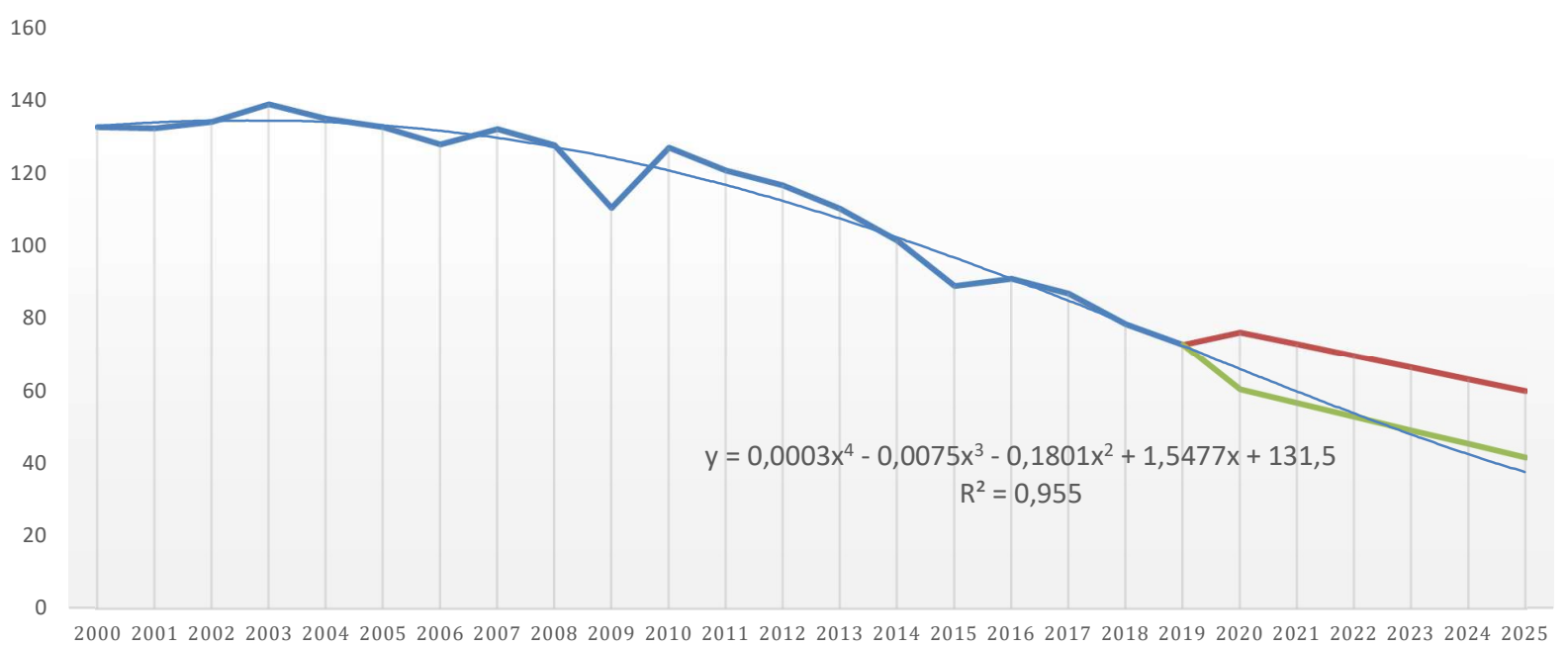

Figure 1. Polynomial-regression analysis of energy efficiency in Ukraine, 2000-2019

Sources: developed by the authors. 
SocioEconomic Challenges, Volume 4, Issue 4, 2020

ISSN (print) - 2520-6621, ISSN (online) - 2520-6214

From figure 1, the following conclusions about trends in the energy efficiency of the country could be highlighted:

First, note that energy efficiency was measured in a million toes, so the smallest level of the indicator - better (the less a country uses fuel per year, in the process of active socioeconomic activity, the greater prospects for its development).

Secondly, it was necessary to note a sharp decline in energy efficiency in 2009, provoked unfortunately not only by positive changes in the country's energy policy but also by several political, social and economic imbalances in the country. The energy efficiency indicator decreased by $17 \%$ in 2009 compared to 2000 , which would be a positive change in general, if not for its further growth and the factors that led to its positive dynamics (flu epidemic, financial crisis, economic downturn, energy wars with the Russian Federation, etc.).

Third, it was advisable to pay attention to the reduction of energy efficiency in 2015 to 88.93 million tons of oil equivalent, which is almost $33 \%$ less than in 2000 , and $19.4 \%$ less than in 2009 . The reasons for this positive trend could be considered an increase in electricity prices by an average of $22 \%$, changes in household incomes caused by inflation, the transition of the energy sector from energy resources of the Russian Federation and the search for new partners in the energy sector - the association of co-owners of an apartment building. All these reasons served to save their energy resources and had a positive impact on the level of energy efficiency.

Fourth, the level of energy efficiency in 2019 amounted to 72.65 million tons of oil equivalent, which was almost twice less than in $2000(45.2 \%)$ and $18.3 \%$ less than in 2015. All these changes indicated positive changes (extending of renewable energy sources, development of the association of co-owners of an apartment building, thermal modification of buildings and structures, etc.) on the way to energy efficiency. However, the factors that affected the indicator were not all positive for the country (industrial production decreased, slow transition to innovative equipment and implementation of treatment facilities). Thus, the main trends in energy efficiency allowed concluding that indicator was multidisciplinary (its value was influenced by ecological, economic, social, political, financial factors).

The results of polynomial regression analysis formed the preconditions for forecasting the level of energy efficiency by 2025 (Fig. 1). According to the optimistic forecast for 2025, the energy efficiency indicator could be about 41.5 million tons of oil equivalent, which was $43 \%$ less than in 2019 . According to the pessimistic forecast, given the uncertainty in the economic, social and political situation, the energy efficiency indicator in 2025 could become about 59-60 million tons of oil equivalent, which was $18 \%$ less than in 2019 , with a polynomial analysis indicate that the values of energy efficiency by 2025 could be less than 40 million tons of oil equivalent, in line with the optimistic forecast (Figure 1).

Five models were developed by grouping the analysed indicators using correlation-regression analysis with the purpose to evaluate the relationship between energy efficiency and 10 indicators of social development. Thus, Model 1 includes the following indicators - Energy efficiency (Intercept), Average life expectancy (X Var1) and the number of retirees (X Var2); Model 2 - Energy efficiency (Intercept), Natural increase, reduction (X Var3) and Migration growth, reduction (X Var4); Model 3 - Energy efficiency (Intercept), Population (X Var5) and Number of the economically active population (X Var6); Model 4 - Energy efficiency (Intercept), Unemployment rate (X Var7) and the number of people with higher education (X Var8); Model 5 - Energy efficiency (Intercept), the population on the brink of poverty (X Var9) and share of household expenditures on housing and utilities (X Var10). 

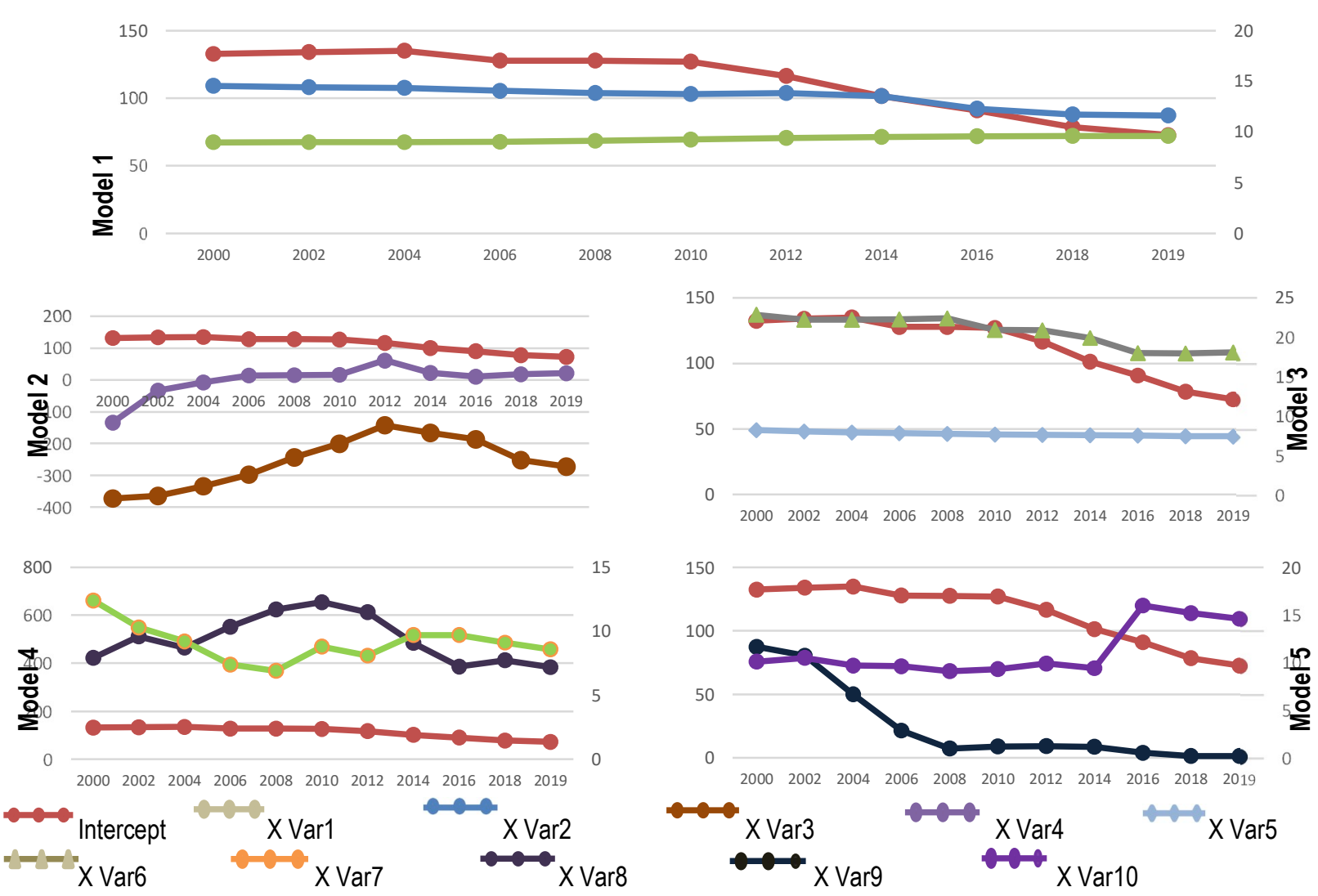

Results of multiple regression analysis

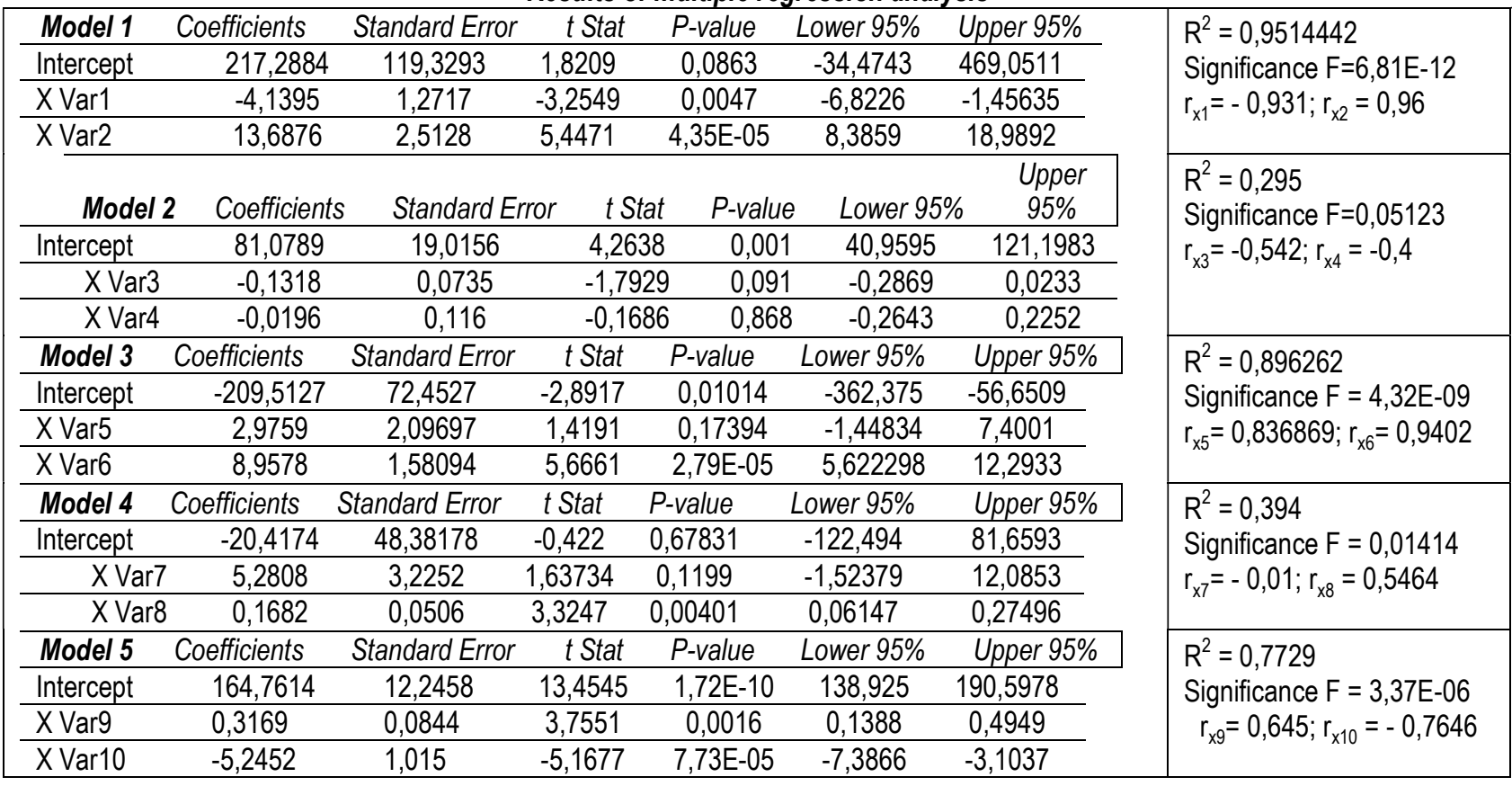

Figure 2. Influence of social indicators on the level of energy efficiency: results of multiple regression analysis, 2000-2019

Sources: developed by the authors. 
According to the calculations presented in Fig.2, the conclusions as follows as:

- Model 1: doubles the correlation coefficient between the index of energy efficiency and the number of pensioners had a strong direct link $\left(\mathrm{r}_{\mathrm{x} 2}=0,96\right)$, and there was a strong direct inverse relationship between energy efficiency and life expectancy $\left(r_{x 1}=-0,931\right)$. It meant that the higher the life expectancy of the population, the lower the value of energy efficiency (older people were more frugal in the use of energy resources), and the smaller the number of people of retirement age, the lower the energy efficiency (in Ukraine there were corresponding discounts on energy prices) provoked households not to save on energy services).

- Model 2: paired correlation coefficients between energy efficiency and natural growth (reduction) and migration growth (reduction) indicators had an average direct inverse relationship $\left(r_{x 3}=-0,542 ; r_{x 4}=-0,4\right)$. Thus, with increasing natural or migratory growth, the energy efficiency indicator could decrease, but it did not significantly affect its value.

- Model 3: paired correlation coefficients between indicators of efficiency and population in the country and the number of economically active people had strong direct links $\left(\mathrm{r}_{\mathrm{x} 5}=0,836869 ; \mathrm{r}_{\mathrm{x} 6}=0,9402\right)$. In the studied case, the decrease in population and the economically active population had a positive statistically significant impact on energy efficiency, but with stable economic and innovative growth, the impact of population on energy efficiency should not be significant.

- Model 4: even correlation coefficients between energy efficiency and unemployment had a weak inverse relationship $\left(\mathrm{r}_{\mathrm{x} 7}=-0,01\right)$, according to the value of the correlation indicator, the unemployment rate did not have a statistically significant effect on the level of energy efficiency. The even correlation coefficient between the value of energy efficiency and the population with higher education had a medium direct relationship $\left(r_{x 8}=0,5464\right)$, it was, the reduction of the studied indicator did not have a significant impact on the level of energy efficiency.

- Model 5: the multiple correlation coefficient between the value of energy efficiency and the population at the poverty line had a direct relationship of medium weight $\left(r_{x 9}=0,645\right)$, and the impact of the indicator, which reflected the share of household expenditures on housing and utilities on energy efficiency, had an inverse statistically significant relationship $\left(\mathrm{r}_{\mathrm{x} 10}=-0,7646\right)$.

During the multi-regression analysis, three models with the largest value of the coefficient of determination were identified: Model $1\left(\mathrm{R}^{2}=0,9514442\right)$; Model $3\left(\mathrm{R}^{2}=0,896262\right)$ and Model $5\left(\mathrm{R}^{2}=0,7729\right)$. It meant that when formulating a strategy to strengthen energy efficiency, it was necessary to focus primarily on improving such social areas of development as the number of people of retirement age and life expectancy, the population, and its economically active part, as well as the population at the border. Poverty and the share of household expenditures aimed at paying for housing and utilities.

Five studied models by grouping the analysed indicators were developed with the purpose to conduct a multiple correlation-regression analysis of the relationships of energy efficiency and 10 indicators of environmental development. Thus, Model 1 includes the following indicators - Energy efficiency (Intercept), Final energy consumption (X Var11) and Water is taken from natural water bodies (X Var12); Model 2 - Energy efficiency (Intercept), Energy productivity (X Var13) and The share of primary energy from renewable sources (X Var14); Model 3 - Energy efficiency (Intercept), The average temperature deviation near the surface (X Var15) and intensity of greenhouse gas emissions from energy consumption (X Var16); Model 4 - Energy efficiency (Intercept), Volumes of pollutant emissions (X Var17) and The volume of generated waste of I-III classes of danger from the economic activity of enterprises and organisations (X Var18); Model 5 - Energy efficiency (Intercept), CO2 emissions from transport (X Var19) and Annual change in interest in renewable energy production (X Var20). 

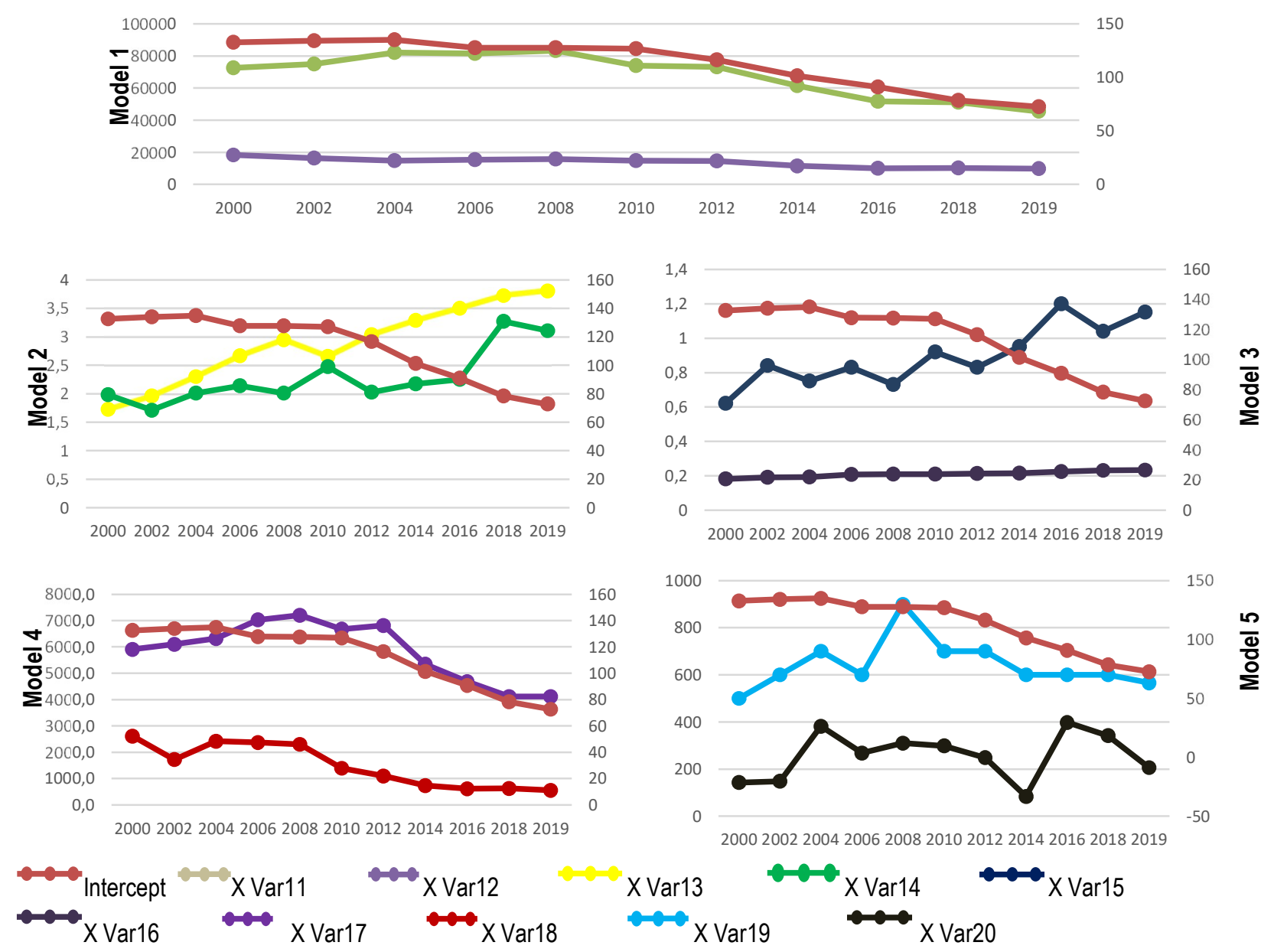

Results of multiple regression analysis

\begin{tabular}{|c|c|c|c|c|c|c|c|}
\hline Model 1 & \multirow{2}{*}{$\begin{array}{r}\text { Coefficients } \\
5621,9492\end{array}$} & \multicolumn{4}{|l|}{ Standard Error } & Upper 95\% & \multirow{4}{*}{$\begin{array}{l}R^{2}=0,9277 \\
\text { Significance } F=2,00 E-10 \\
r_{x 11}=0,9428 ; r_{x 12}=0,922\end{array}$} \\
\hline Intercept & & 7562,2705 & 0,7434 & 0,4674 & $-10333,0469$ & 21576,9452 & \\
\hline X Variable11 & 0,9562 & 0,2236 & 4,2754 & 0,0005 & 0,4843 & 1,428035 & \\
\hline X Variable12 & 3,1105 & 1,03004 & 3,0198 & 0,0077 & 0,9373 & 5,2837 & \\
\hline Model 2 & Coefficients & tandard Error & $t$ Stat & $P$-value & Lower 95\% & Upper 95\% & $R^{2}=0.83667$ \\
\hline Intercept & 208,715 & 10,7731 & 19,3737 & $5,03 \mathrm{E}-1$ & $13 \quad 185,9858$ & 231,4442 & Significance $F=2,05 E-07$ \\
\hline & $-0,02498$ & 0,0044 & $-5,73593$ & $2,42 \mathrm{E}-0$ & $-0,03417$ & $-0,01579$ & $r_{x 13}=-0,899 ; r_{x 14}=-0,722$ \\
\hline & ar14 $\quad-10,2593$ & 5,9534 & $-1,7233$ & 0,10297 & $\begin{array}{ll}77 & -22,8199 \\
\end{array}$ & 2,301241 & \\
\hline Model 3 & Coefficients $\quad S t$ & tandard Error & t Stat & $P$-value & Lower 95\% & Upper 95\% & $R^{2}=0,8237$ \\
\hline Intercept & 342,2234 & 37,4347 & 9,1419 & 5,67E-08 & 263,2431 & 421,2036 & Significance $F=3,91 \mathrm{E}-10$ \\
\hline X Var15 & $-47,7414$ & 25,136 & $-1,8993$ & 0,0746 & $-100,774$ & 5,29097 & $r_{x 15}=-0,836 ; r_{x 16}=-0,887$ \\
\hline $\mathrm{X} \operatorname{Var} 16$ & $-882,212$ & 254,8173 & $-3,4621$ & 0,00298 & $-1419,83$ & $-344,595$ & \\
\hline Model 4 & Coefficients $\quad S t$ & tandard Error & $t$ Stat & $P$-value & Lower 95\% & Upper 95\% & $R^{2}=0,8936$ \\
\hline Intercept & 39,55 & 10,1973 & 3,8785 & 0,0012 & 18,036 & 61,0649 & Significance $F=5,35 E-09$ \\
\hline & 0,0087 & 0,0021 & 4,1923 & 0,0006 & 0,0043 & 0,013 & $r_{x 17}=0,8352 ; r_{x 18}=0,8852$ \\
\hline & 0,0152 & 0,0027 & 5,5971 & $3,21 \mathrm{E}-05$ & 0,0095 & 0,0209 & \\
\hline Model 5 & Coefficients $\quad S t$ & tandard Error & t Stat & $P$-value & Lower 95\% & Upper 95\% & $R^{2}=0,0998$ \\
\hline Intercept & 73,0455 & 32,0508 & 2,2791 & 0,0359 & 5,4242 & 140,6669 & Significance $F=0,4091$ \\
\hline & 64,0436 & 48,5392 & 1,3194 & 0,2045 & $-38,3652$ & 166,4525 & $r_{x 19}=0,288 ; r_{x 20}=-0,0874$ \\
\hline & $-0,1405$ & 0,2503 & $-0,5612$ & 0,582 & $-0,6686$ & 0,3877 & \\
\hline
\end{tabular}

Figure 3. Influence of environmental indicators on the level of energy efficiency: results of multiple regression analysis, 2000-2019

Sources: developed by the authors. 
SocioEconomic Challenges, Volume 4, Issue 4, 2020

ISSN (print) - 2520-6621, ISSN (online) - 2520-6214

Considering the findings in Figure 3, the core conclusions as follows as:

- Model 1: Paired correlation coefficients between energy efficiency, final energy consumption and abstracted water from natural water bodies had strong direct links $\left(r_{x 11}=0,9428 ; r_{x 12}=0,922\right)$. It meant that the lower the values of environmental indicators, the more positively they affected the level of energy efficiency.

- Model 2: paired correlation coefficients between energy efficiency and energy performance indicators and the share of primary energy from renewable sources have a strong direct inverse relationship $\left(r_{x 13}=-0,899\right.$; $r_{x 14}=-$ 0,722). Thus, with increasing environmental indicators X Var13 and X Var14 will significantly affect the value of energy efficiency.

- Model 3: paired correlation coefficients between energy efficiency, and the average deviation of air temperature, the intensity of greenhouse gas emissions during energy consumption had strong direct inverse relationships $\left(r_{x 15}=-0,836 ; r_{x 16}=-0,887\right)$. In the studied case, when reducing the level of energy efficiency by increasing the indicators X Var15 and X Var16 should always be under control because these indicators should tend to decrease under the condition of energy efficiency.

- Model 4: even correlation coefficients between energy efficiency values and pollutant emissions generated by wastes of hazard classes I-III from economic activities of enterprises and organisations had a strong direct relationship $\left(\mathrm{r}_{\mathrm{x} 17}=0,8352 ; \mathrm{r}_{\mathrm{x} 18}=0,8852\right)$, it was, the reduction of the studied indicators had a significant impact on the level of energy efficiency.

- Model 5: pairwise correlation coefficients between energy efficiency and CO2 emissions from transport had a direct weak weight relationship $\left(\mathrm{r}_{\mathrm{x} 19}=0,288\right)$, and the impact of an indicator that reflects the annual change in interest in renewable energy production was inversely weak $\left(\mathrm{r}_{\mathrm{x} 20}=-0,0874\right)$. It was advisable to pay attention to the relationship between energy efficiency and X Var20, under conditions of stable development in the direction of carbon neutrality, this indicator should had an inverse relationship of medium or strong weight, because due to the introduction of renewable sources in production energy efficiency increases.

When conducting a multi-regression analysis of environmental indicators with energy efficiency, four models with the highest value of the coefficient of determination were identified: Model $1\left(\mathrm{R}^{2}=0,9277\right)$; Model 2 $\left(\mathrm{R}^{2}=0,83667\right)$, Model $3\left(\mathrm{R}^{2}=0,8237\right)$ and Model $4\left(\mathrm{R}^{2}=0,8936\right)$. It meant that compared to previous indicators of the social component, environmental indicators have a greater impact on energy efficiency, i.e., when formulating a strategy to strengthen energy efficiency, it was necessary to focus on improving all possible environmental indicators, because they were interconnected and develop the ecological-innovative potential of entrepreneurial activity. Five models were developed by grouping the analysed indicators with the purpose to conduct a multiple correlation-regression analysis of the relationships of energy efficiency and 10 indicators of economic development. Thus, Model 1 includes the following indicators - Energy efficiency (Intercept), Current costs of environmental protection (X Var21) and GDP per capita (X Var22); Model 2 - Energy efficiency (Intercept), Industrial production indices (X Var23) and Agricultural production indices (X Var24); Model 3 Energy efficiency (Intercept), The volume of transported goods (X Var25) and The volume of transported passengers (X Var26); Model 4 - Energy efficiency (Intercept), Consumer price index (X Var27) and The share of the number of innovatively active enterprises in the total number of industrial enterprises (X Var28); Model 5 - Energy efficiency (Intercept), Foreign direct investment, net inflow (X Var29) and Energy intensity vs GDP per capita (X Var30). 

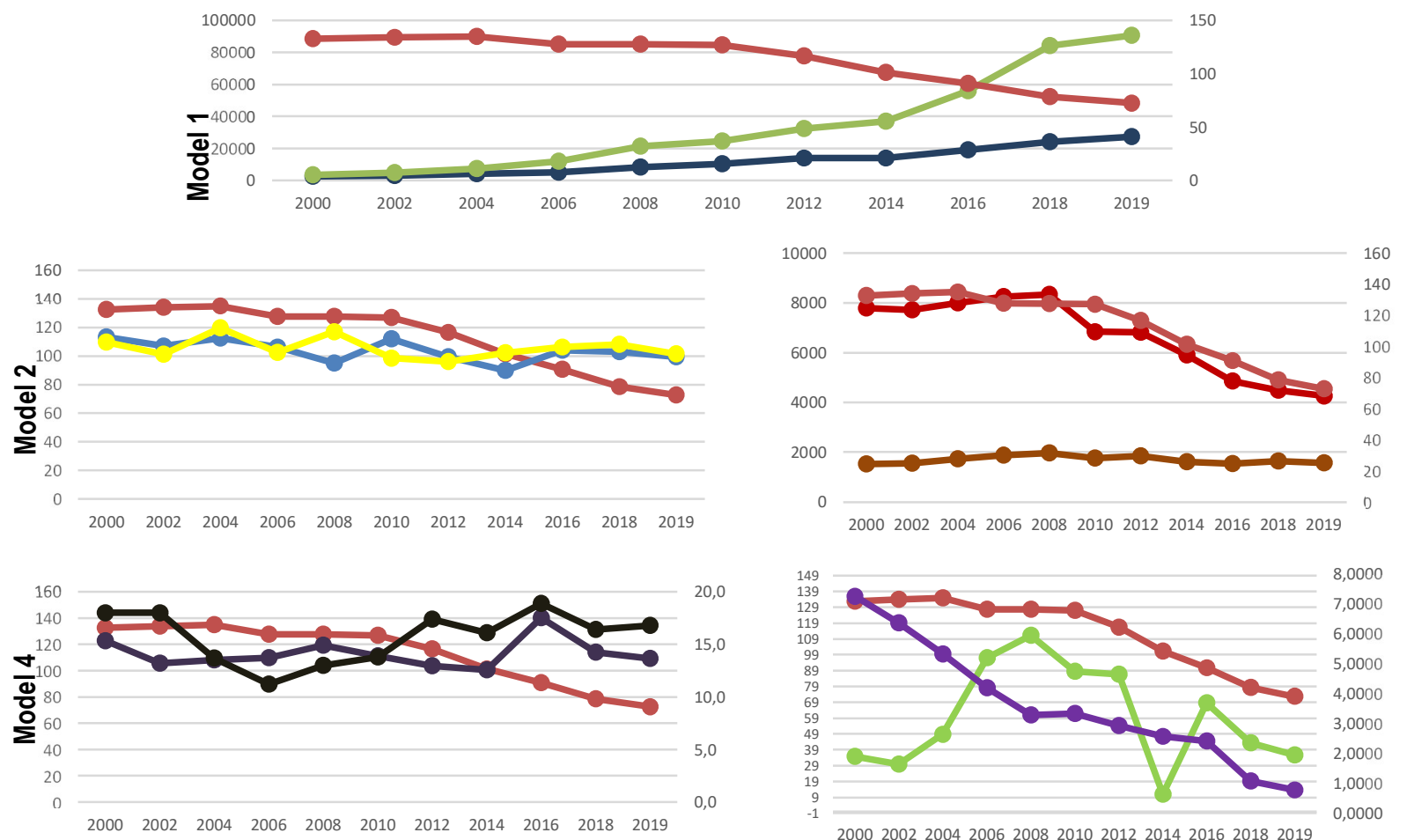

$\frac{10}{\frac{0}{0}}$

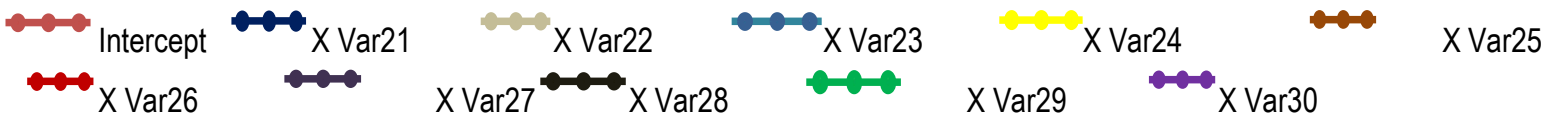

Results of multiple regression analysis

\begin{tabular}{|c|c|c|c|c|c|c|c|}
\hline Model 1 & Coefficients & $\begin{array}{c}\text { Standard } \\
\text { Error }\end{array}$ & $t$ Stat & $P$-value & Lower 95\% & Upper 95\% & \multirow{4}{*}{$\begin{array}{l}\mathrm{R}^{2}=0,9214 \\
\text { Significance } \mathrm{F}=4,1 \mathrm{E}-10 \\
\mathrm{r}_{\mathrm{x} 21}=-0,956 ; \mathrm{r}_{\mathrm{x} 22}=-0,958\end{array}$} \\
\hline Intercept & 141,0369 & 3,8087 & 37,0303 & $1,07 \mathrm{E}-17$ & 133,0012 & 149,0725 & \\
\hline $\mathrm{X}$ Var21 & $-1,1 \mathrm{E}-06$ & $1,21 \mathrm{E}-06$ & $-0,94078$ & 0,359994 & $-3,7 \mathrm{E}-06$ & $1,41 \mathrm{E}-06$ & \\
\hline $\mathrm{X}$ Var22 & $-0,00044$ & 0,0003 & $-1,2998$ & 0,211015 & $-0,00116$ & 0,000276 & \\
\hline Model 2 & Coefficients & $\begin{array}{l}\text { Standard } \\
\text { Error }\end{array}$ & $t$ Stat & $P$-value & Lower $95 \%$ & Upper $95 \%$ & \multirow{4}{*}{$\begin{array}{l}\mathrm{R}^{2}=0,2681 \\
\text { Significance } \mathrm{F}=0,0704 \\
\mathrm{r}_{\mathrm{x} 23}=0,5174 ; \mathrm{r}_{\mathrm{x} 24}=0,095\end{array}$} \\
\hline Intercept & $-6,9809$ & 65,4911 & $-0,1066$ & 0,9164 & $-145,155$ & 131,1932 & \\
\hline X Var23 & 1,13501 & 0,4626 & 2,4534 & 0,0252 & 0,1589 & 2,1111 & \\
\hline X Var24 & 0,0505 & 0,5017 & 0,1007 & 0,92099 & $-1,00801$ & 1,10903 & \\
\hline Model 3 & Coefficients & $\begin{array}{l}\text { Standard } \\
\text { Error }\end{array}$ & $t$ Stat & $P$-value & Lower 95\% & Upper 95\% & \multirow{4}{*}{$\begin{array}{l}\mathrm{R}^{2}=0,9247 \\
\text { Significance } \mathrm{F}=2,8 \mathrm{E}-10 \\
\mathrm{r}_{\mathrm{x} 25}=0,4335 ; \mathrm{r}_{\mathrm{x} 26}=0,957\end{array}$} \\
\hline Intercept & 36,5927 & 15,4585 & 2,3672 & 0,0301 & 3,9782 & 69,2073 & \\
\hline $\mathrm{X}$ Var25 & $-1,5 \mathrm{E}-05$ & $1,06 \mathrm{E}-05$ & $-1,43502$ & 0,1694 & $-3,8 \mathrm{E}-05$ & $7,18 \mathrm{E}-06$ & \\
\hline $\mathrm{X}$ Var26 & $1,54 \mathrm{E}-05$ & $1,19 \mathrm{E}-06$ & 12,8963 & $3,32 \mathrm{E}-10$ & $1,29 \mathrm{E}-05$ & $1,79 \mathrm{E}-05$ & \\
\hline Model 4 & Coefficients & $\begin{array}{l}\text { Standard } \\
\text { Error }\end{array}$ & $t$ Stat & $P$-value & Lower 95\% & Upper 95\% & \multirow{4}{*}{$\begin{array}{l}\mathrm{R}^{2}=0,2017 \\
\text { Significance } \mathrm{F}=0,1473 \\
\mathrm{r}_{\mathrm{x} 27}=-0,249 ; \mathrm{r}_{\mathrm{x} 28}=-0,414\end{array}$} \\
\hline Intercept & 213,0444 & 55,6264 & 3,8299 & 0,0013 & 95,6829 & 330,4059 & \\
\hline X Var27 & $-0,3628$ & 0,45197 & $-0,8027$ & 0,4332 & $-1,3164$ & 0,5908 & \\
\hline X Var28 & $-3,6854$ & 2,1346 & $-1,7265$ & 0,1024 & $-8,189$ & 0,8183 & \\
\hline Model 5 & Coefficients & $\begin{array}{l}\text { Standard } \\
\text { Error } \\
\end{array}$ & $t$ Stat & P-value & Lower 95\% & Upper 95\% & \multirow{4}{*}{$\begin{array}{l}\mathrm{R}^{2}=0,8543 \\
\text { Significance } \mathrm{F}=7,8 \mathrm{E}-08 \\
\mathrm{r}_{\mathrm{x} 29}=0,3532 ; \mathrm{r}_{\mathrm{x} 30}=0,849\end{array}$} \\
\hline Intercept & 65,4239 & 5,5807 & 11,7233 & $1,44 \mathrm{E}-09$ & 53,6497 & 77,19802 & \\
\hline X Var29 & 3,7556 & 0,9539 & 3,9371 & 0,0011 & 1,74303 & 5,76809 & \\
\hline $\mathrm{X}$ Var30 & 9,7449 & 1,0564 & 9,2246 & $4,99 \mathrm{E}-08$ & 7,5161 & 11,9737 & \\
\hline
\end{tabular}

Figure 4. Influence of economic indicators on the level of energy efficiency: results of multiple regression analysis, 2000-2019

Sources: developed by the authors. 
SocioEconomic Challenges, Volume 4, Issue 4, 2020

ISSN (print) - 2520-6621, ISSN (online) - 2520-6214

Considering the findings in Fig. 4 the following conclusions could be highlighted:

- Model 1: Paired correlation coefficients between energy efficiency, current environmental expenditures and GDP per capita had a strong inverse relationship $\left(\mathrm{r}_{\mathrm{x} 21}=-0,956 ; \mathrm{r}_{\mathrm{x} 22}=-0,958\right)$. It confirmed that the higher the value of the studied indicators, the lower the energy efficiency index.

- Model 2: the pairwise correlation coefficient between the energy efficiency indicator and the industrial production index had a direct relationship of average weight $\left(\mathrm{r}_{\mathrm{x} 23}=0,5174\right)$, and there was a weak direct link between energy efficiency and the agricultural index $\left(\mathrm{r}_{\mathrm{x} 24}=0,095\right)$. It should be noted that the inverse model of energy efficiency relations with indices of industrial and industrial production would be effective for the country. Thus, it would be possible to assert the sustainable development of energy efficiency at the micro and macro levels.

- Model 3: the pairwise correlation coefficient between the energy efficiency indicator and the volume of cargo transportation had direct links of medium weight $\left(\mathrm{r}_{\mathrm{x} 25}=0,4335\right)$, and strong direct links between energy efficiency and the volume of passengers carried $\left(\mathrm{r}_{\mathrm{x} 26}=0,957\right)$. In the case under study, the reduction in passenger traffic had a positive effect on the value of energy efficiency.

- Model 4: the pair correlation coefficient between the value of energy efficiency and the consumer price index was a weak inverse relationship $\left(\mathrm{r}_{\mathrm{x} 27}=-0,249\right)$, according to the value of the correlation index did not affect the level of energy efficiency. The even correlation coefficient between the value of energy efficiency and the share of innovatively active enterprises in the total number of industrial enterprises had an average inverse relationship $\left(\mathrm{r}_{\mathrm{x} 28}=-0,414\right)$, it was, changes in the studied indicators did not have a significant impact on the level of energy efficiency.

- Model 5: even correlation coefficients between energy efficiency and foreign direct investment (net inflow) had a direct relationship of medium weight $\left(\mathrm{r}_{\mathrm{x} 29}=0,3532\right)$, and the impact of an indicator that reflects the energy intensity of GDP per capita on the level of energy efficiency had a direct relationship of vital importance $\left(\mathrm{r}_{\mathrm{x} 30}=0,849\right)$.

When conducting a multi-regression analysis of the formalisation of the relationship of economic indicators for energy efficiency, three models with the highest value of the coefficient of determination were identified: Model $1\left(\mathrm{R}^{2}=0,9214\right)$; Model $3\left(\mathrm{R}^{2}=0,9247\right)$ and Model $5\left(\mathrm{R}^{2}=0,8543\right)$. It means that when formulating a strategy to strengthen energy efficiency positions, it was necessary to focus primarily on improving such economic areas of development as current environmental costs, GDP per capita, the volume of passengers carried, the energy intensity of GDP per capita.

\section{Conclusion}

The conducted multi-regression analysis allowed to study 30 indicators of social, ecological and economic development and to highlit appropriate conclusions about their impact on the level of energy efficiency. Thus, to increase the energy efficiency potential of the country, it was necessary to act with a functional sequence adhering to a sustainable development strategy and pay attention to such problematic targets and ways to solve them:

1. Develop an effective subsidy program for all segments of the population, which will be focused on energy-efficient use of housing and communal services - it allows increasing the interest of the population to save their energy resources.

2. Promotion and support among households of associations in the association of apartment building coowners, for further control, thermal modification and energy-saving opportunities for their buildings.

3. Incentives by the state through the green investment of enterprises that implement renewable energy sources, energy-saving and innovative technologies in production, which allow reducing the energy intensity of the country's GDP and strengthen competitive positions in the international market. 
4. Replacement of traditional energy sources (fossil fuels, gas) with renewables (solar, wind, hydro and bioenergy), it allows becoming an energy-independent country in the future.

5. State support of enterprises for processing of secondary raw materials and the implementing of closed cycles in their production.

6. To extend municipal electric cars among the passenger transportation sector and transition to ecological types of cargo circulation (river, air, sea).

Funding: The research was funded by the grant from the National Research Foundation of Ukraine «Stochastic modelling of road map for harmonising national and European standards for energy market regulation in the transition to a circular and carbon-free economy» ID 2020.02/0231); grants from the Ministry of Education and Science of Ukraine (No 0120U102002).

Author Contributions: conceptualization, Yevheniia Ziabina, Tetyana Pimonenko; methodology, Yevheniia Ziabina, Tetyana Pimonenko; validation, Yevheniia Ziabina, Tetyana Pimonenko; formal analysis, Luidmyla Starchenko; investigation, Yevheniia Ziabina, Tetyana Pimonenko; resources, Yevheniia Ziabina, Tetyana Pimonenko; data curation, Luidmyla Starchenko; writing original draft preparation, Yevheniia Ziabina, Tetyana Pimonenko; writing review and editing, Yevheniia Ziabina, Tetyana Pimonenko; visualization, Yevheniia Ziabina, Tetyana Pimonenko; supervision, Yevheniia Ziabina, Tetyana Pimonenko; project administration, Yevheniia Ziabina, Tetyana Pimonenko.

\section{References}

1. Bhowmik, D. (2019). Decoupling CO2 Emissions in Nordic countries: Panel Data Analysis. Socio Economic Challenges, 3(2), 15-30. http://doi.org/10.21272/sec.3(2).15-30.2019.

2. Bilan, Y., Raišienè, A. G., Vasilyeva, T., Lyulyov, O., \& Pimonenko, T. (2019). Public governance efficiency and macroeconomic stability: Examining convergence of social and political determinants. Public Policy and Administration, 18(2), 241-255. doi:10.13165/VPA-19-18-2-05. Retrieved from: https://www3.mruni.eu/ojs/public-policy-and-administration/article/view/4865.

3. Bozhkova, V., Ptashchenko, O., Saher, L., \& Syhyda, L. (2018). Transformation of marketing communications tools in a globalising environment. Marketing and innovation management, 1, 73-82. DOI: 10.21272/mmi.2018.1-05. Retrieved from: https://mmi.fem.sumdu.edu.ua/en/journals/2018/1/73-82.

4. Caruso, G., Colantonio, E., Gattone, S.A. (2020). Relationships between Renewable Energy Consumption, Social Factors, and Health: A Panel Vector Auto Regression Analysis of a Cluster of 12 EU Countries. Sustainability, 12(7), 2915. doi:10.3390/su12072915. https://www.mdpi.com/2071-1050/12/7/2915.

5. Chigrin, O., Scherbak, A. (2011) Analysis of the main problems of ecologically pure production implementation in Ukraine. Mechanism of economic regulation. 1, 235-241. Retrieved from: https ://www.esdconference.com/upload/book_of_proceedings/Book_of_Proceedings_esdBaku2020Vol1_Online.pdf.

6. Chygryn, O., Petrushenko, Y., Vysochyna, A., \& Vorontsova, A. (2018). Assessment of Fiscal Decentralisation Influence on Social and Economic Development. Montenegrin Journal of Economics, 14(4), 069-084. Retrieved from: https://www.researchgate.net/publication/329687891_Assessment of _Fiscal_Decentrali zation_Influence_on_Social_and_Economic_Development

7. Chygryn, O., Pimonenko, T., Luylyov, O., \& Goncharova, A. (2018). Green Bonds like the Incentive Instrument for Cleaner Production at the Government and Corporate Levels Experience from EU to Ukraine. Journal of Advanced Research in Management, 9(7), 1443-1456. Retrieved from: https://journals.aserspublishing.eu/jemt/article/view/2738

8. European Statistical Office [Electronic resource]. Retrieved from: https://ec.europa.eu/eurostat/statisticsexplained/index.php/Electricity price statistics.

9. Ibragimov, Z., Lyeonov, S., \& Pimonenko, T. (2019). Green investing for SDGS: EU experience for developing countries. Economic and Social Development: Book of Proceedings, 867-876. Retrieved from: https://scholar.google.com/scholar?cluster $=5676250165736788917 \& h l=u k \& a s \quad$ sdt $=0,5$.

10. Ibragimov, Z., Vasylieva, T., \& Lyulyov, O. (2019). The national economy competitiveness: effect of 
macroeconomic stability, renewable energy on economic growth. Economic and Social Development: Book of Proceedings, 877-886. Retrieved from: https://essuir.sumdu.edu.ua/handle/123456789/80913.

11. Kostel, M., Leus, D., Cebotarenco, A., Mokrushina, A. (2017). The Sustainable Development Goals for Eastern Partnership Countries: Impact of Institutions. SocioEconomic Challenges, 1(3), 79-90. http://doi.org/10.21272/sec.1(3).79-90.2017.

12. Kouassi. K. B. (2018). Public Spending and Economic Growth in Developing Countries: a Synthesis. Financial Markets, Institutions and Risks, 2(2), 22-30. http://doi.org/10.21272/fmir.2(2).22-30.2018.

13. Letunovska, N.Ye. (2019). Innovative marketing approaches to promote the consumption of tourist product. Proceedings of the conference "III International Scientific Conference" Corporate governance: strategies, processes, technology, Leipzig, Germany, 73-75. Retrieved from: https://essuir.sumdu. edu.ua /bitstream/123456789/75842/1/Letunovska abstract.pdf.

14. Letunovskaya N. (2013). Social innovations of enterprises in the conditions of transformational economy. Innovative economy, 4, 107-112. Retrieved from: http://www.wydawnictwo.wst.pl/uploads/files/ 10ce27dda4eab6e1ad0c1e55ca02e9cd.pdf.

15. Letunovskaya N. (2014). Social infrastructure of an industrial enterprise and its importance in the system of personnel motivation. Marketing and innovation management. 1, 259-269. Retrieved from: https://mmi.fem.sumdu.edu.ua/en/journals/2014/1/259-269.

16. Liulov, O., Pimonenko, T, Stoyanets N., Letunovska, N. (2019). SustainableDevelopment of Agricultural Sector: Democratic Profile Impact Among Developing Countries. Research in World Economy, 10(4), 97 105. https://doi.org/10.5430/rwe.v10n4p97.

17. Lyeonov, S., Pimonenko, T., Bilan, Y., Štreimikienè, D., \& Mentel, G. (2019). Assessment of Green Investments' Impact on Sustainable Development: Linking Gross Domestic Product Per Capita, Greenhouse Gas Emissions and Renewable Energy. Energies, 12(20), 3891. https://doi.org/10.3390/en12203891.

18. Lyulyov, O. V., \& Pimonenko, T. V. (2017). Lotka-Volterra model as an instrument of the investment and innovative processes stability analysis. Marketing and Management of Innovations, 1, 159-169. http://doi.org/10.21272/mmi.2017.1-14.

19. Mačaitytè, I., Virbašiūtė, G. (2018). Volkswagen Emission Scandal and Corporate Social Responsibility A Case Study. Business Ethics and Leadership, 2(1), 6-13. http://doi.org/10.21272/bel.2(1).6-13.2018.

20. Makarenko, I., Sirkovska, N. (2017). Transition to sustainability reporting: evidence from EU and Ukraine. Business Ethics and Leadership, 1(1), 16-24. http://doi.org/10.21272/bel.2017.1-02.

21. Marques, A. C., Fuinhas, J. A., Tomas, Carla (2019). Energy efficiency and sustainable growth in industrial sectors in European Union countries: A nonlinear ARDL approach. Journal of Cleaner Production, 239, 118045. http://doi.org/10.21272/bel.2017.1-02.

22. Matsenko, A., Chigrin, E., Taranovsky, V., Dolgodush A. Socio-ecological-economic challenges of water supply in Ukraine. Mechanism of economic regulation, 4, 264-271. Retrieved from: https://mer.fem.sumdu.edu.ua/index.php?cmd=view article\&article id=222\&issue id=15\&lang=en\&.

23. National Institute for Strategic Studies. Retrieved from: https://niss.gov.ua/.

24. Nelson, E. M. (2017). Socioeconomic Challenges - A Global Perspective Evaluating Invisible Connections-Resolutioning Necessary Global Collaborative. SocioEconomic Challenges, 1(3), 116-119. http://doi.org/10.21272/sec.1(3).116-119.2017.

25. Olefirenko, O., Letunovska, N., Shevliuga O. (2019). System approach to the development of sales policy of innovative-active industrial enterprises. Scientific Bulletin of Uzhhorod National University. Series: International Economic Relations and the World Economy, 25(2), 20-24. Retrieved from: https://www.uzhnu.edu.ua/en/cat/faculty-fhistory relati/material.

26. Palienko M., Lyulyov O., Denysenko P. (2017). Fiscal Decentralisation as a Factor of Macroeconomic Stability of the Country. Financial Markets, Institutions and Risks, 1(4), 74-86. http://doi.org/10.21272/fmir.1(4).74-86.2017.

27. Panchenko, V., Harust, Yu., Us, Ya., Korobets, O., \& Pavlyk, V. (2020). Energy-Efficient Innovations: Marketing, Management and Law Supporting. Marketing and Management of Innovations, 1, 256-264. http://doi.org/10.21272/mmi.2020.1-21. 
28. Pantelis, C., Tasios, N., De Vita, A, Mantzos, L., Paroussos, L. (2012). Model-based analysis of decarbonising the EU economy in the time horizon to 2050. European Energy System Models, 1(2). http://doi.org/10.1016/j.esr.2012.06.003.

29. Pavlyk, V. (2020). Assessment of green investment impact on the energy efficiency gap of the national economy. Financial Markets, Institutions and Risks, 4(1), 117-123. http://doi.org/10.21272/fmir.4(1).117123.2020 .

30. Pilia, G. (2017). Estonia and Lithuania in transition: A compared analysis of the change and its costs and benefits. Business Ethics and Leadership, 1(2), 12-19. http://doi.org/10.21272/bel.1(2).12-19.2017.

31. Pimonenko T, Chygryn O., Luylov O. (2018). Green Entrepreneurship as an Integral Part of the National Economy Convergence. National Security \& Innovation Activities: Methodology, Policy and Practice: monograph / edited by Dr. of Economics, Prof. O. Prokopenko, Ph.D in Economics V. Omelyanenko, Ph.D in Technical Sciences, Assoc. Prof. Yu. Ossik. - Ruda Śląska: Drukarnia i Studio Graficzne Omnidium, 358-365. Retrieved from: http://visnykj.wunu.edu.ua/index.php/visnykj/article/view/810/0.

32. Pimonenko, T. (2018). Ukrainian Perspectives for Developing Green Investment Market: EU Experience. Economics and Region, 4(71), 35-45. Retrieved from: https:/essuir.sumdu.edu.ua/ handle/ 123456789/80351.

33. Pimonenko, T., Lyulyov, O., Chygryn, O., \& Palienko, M. (2018). Environmental Performance Index: relation between social and economic welfare of the countries. Environmental Economics, 9(3), 7-16. http://doi.org/10.21511/ee.09(3).2018.01.

34. Pimonenko, T., Yu, M., Korobets, O., \& Lytvynenko, O. (2017). Ecological stock indexes: foreign experience and lessons for Ukraine. Bulletin of Sumy State University. Economy Ser, 4, 121-127. Retrieved from: http://visnykj.wunu.edu.ua/index.php/htneu/article/view/879.

35. Ritchie, H., Roser, M. (2020). $\mathrm{CO}_{2}$ and Greenhouse Gas Emissions. Our World in Data. Retrieved from https://ourworldindata.org/co2-and-other-greenhouse-gas-emissions.

36. Samoilikova, A. (2020). Financial Policy of Innovation Development Providing: The Impact Formalization. Financial Markets, Institutions and Risks, 4(2), 5-15. https://doi.org/10.21272/fmir.4(2).515.2020 .

37. Singh, S.N. (2019). Climate Change and Agriculture in Ethiopia: A Case Study of Mettu Woreda. SocioEconomic Challenges, 3(3), 61-79. http://doi.org/10.21272/sec.3(3).61-79.2019.

38. Singh, S.N. (2020). Household's Willingness to Pay for Improved Water Supply Services in Mettu Town: An Assessment. Financial Markets, Institutions and Risks, 4(1), 86-99. http://doi.org/10.21272/ fmir.4(1).86-99.2020.

39. Spremberg, E., Tykhenko, V., Lopa, L. (2017). Public-Private Partnership in the Implementation of National Environmental Projects. SocioEconomic Challenges, 1(4), 73-81. http://doi.org/10.21272sec.1(4).73-81.2017

40. State Statistics Service of Ukraine. Retrieved from: http://www.ukrstat.gov.ua/

41. Vashchenko, T., Letunovskaya, N. (2018). The role of innovative small business in solving the problem of import substitution and increasing the competitiveness of the industrial sector as a condition to ensure rapid development. Black Sea Economic Studies, 31, 49-52. Retrieved from: http://nbuv.gov.ua/UJRN/ bses 20183111.

42. World Meteorological Organization. (2020). Retrieved from: https://ibrary.wmo.int/index.php?lvl=notice display\&id=21777\#.X6qP1EX7TIW.

43. Yelnikova J., Kwilinski A. (2020). Impact-Investing in The Healthcare in Terms of the New Socially Responsible State Investment Policy. Business Ethics and Leadership, 4(3), 57-64. https://doi.org/10.21272/bel.4(3).57-64.2020.

44. Yevdokimov, Y., Chygryn, O., Pimonenko, T., \& Lyulyov, O. (2018). Biogas as an alternative energy resource for Ukrainian companies: EU experience. Innov. Mark, 14, 7-15. Retrieved from: https://essuir.sumdu.edu.ua/handle/123456789/80303.

45. Ziabina, Y., \& Pimonenko, T. (2020). The Green Deal Policy for Renewable Energy: A Bibliometric Analysis. Virtual Economics, 3(4), 147-168. https://doi.org/10.34021/ve.2020.03.04(8).

46. Ziabina, Ye. (2016) Theoretical aspects of the formation of green economy in the context of sustainable 
ISSN (print) - 2520-6621, ISSN (online) - 2520-6214

development. Mechanism of Economic Regulation. 3, 116-121. Retrieved from: https://mer.fem.sumdu.edu.ua/content/acticles/issue_30/YEVHENIIA_A_ZIABINATheoretical_Aspects of the_Formation_of_Green_Economy_in the Context_of_Sustainable_Development.pdf.

47. Ziabina, Ye., Lyulyov, O., \& Pimonenko, T. (2019) Development of green energy as a way to energy independence of the national economy: experience of EU countries. Scientific Bulletin of Polissia, 19(3), 39-48. https://doi.org/10.25140/2410-9576-2019-3(19)-39-48. 